\title{
Motivating and engaging volunteer hunters to control the invasive alien American mink Neovison vison in Norway
}

\author{
J. STIEN and V. H. HAUSNER
}

\begin{abstract}
Invasive alien species can have widespread negative effects on native biodiversity. We investigated the prospects of engaging hunters in large-scale collaborative efforts to control non-native mink Neovison vison populations in Norway. We invited members of the Norwegian Association of Hunters and Anglers to complete an online questionnaire to ascertain their support for conservation and their level of effort to remove mink, in the context of hunting motivations and bounty payments. The general interest in mink control programmes was low but participants perceived the mink to be of conservation concern. Bounty payments influenced mink catches, with hunters who received payments catching a mean of 4.70 more individuals per hunter than those who did not receive payments $(\mathrm{P}<0.001)$. Mink hunters who preferred to hunt alone and had no preference for hunting locally reportedly caught on average 1.87 more mink per hunter than those who preferred to hunt in company $(\mathrm{P}<0.001)$. The majority of hunters preferred government-led programmes ( $47 \%)$, and investment in bounty programmes $(52 \%)$ was their main recommendation to improve mink hunting. Hunters can be a valuable component of a mink removal task force and could decrease the likelihood of recolonization of mink in the buffer areas of core conservation target areas.
\end{abstract}

Keywords Alien species, conservation action, ground-nesting birds, invasive species, local community, mink, Neovison vison, predator

The supplementary material for this article can be found at https://doi.org/10.1017/So030605316000879

\section{Introduction}

Tnvasive alien species are among the primary drivers of biodiversity loss globally (Poorter et al., 2007; Kettunen et al., 2008). Among the species causing concern in northern Europe is the American mink Neovison vison, which

J. StiEn (Corresponding author) Norwegian Institute for Nature Research, Framsenteret, Postboks 6606 Langnes, 9296 Tromsø, Norway

E-mail jennifer.stien@nina.no

V. H. HAusner Department of Arctic and Marine Biology, The Arctic University of Norway, Tromsø, Norway

Received 14 January 2016. Revision requested 29 February 2016. Accepted 28 July 2016. First published online 20 January 2017. escaped from mink farms across Europe at the beginning of the 2oth century and subsequently established widespread feral populations (Sheail, 2004; Bonesi \& Palazon, 2007; Reynolds, 2009). Without natural enemies and being a generalist predator, the mink has had negative effects on European populations of native species, including globally threatened waders and seabirds, passerines, small mammals and reptiles (e.g. Nordström et al., 2003; Ahola et al., 2006; Bonesi \& Palazon, 2007). Apart from a few notable success stories (Bonesi \& Palazon, 2007; Bryce et al., 2011), there is a history of failed conservation efforts aimed at eradication or control of mink. Although numbers may be reduced to acceptable levels, maintaining mink-free areas is labour intensive, requiring ongoing control that may also include buffer zones adjacent to the target conservation zones (Robertson et al., 2016).

Large-scale collaborative efforts including nonprofessional hunters or trappers could potentially retain sufficient manpower to facilitate initial removal and control recolonization in targeted areas. Hunters could be motivated to participate in collaborative removal efforts because of their personal engagement in safeguarding threatened species or protecting fish and game populations for consumptive uses. Where intrinsic motivation to protect native species is strong, hunters could be encouraged to contribute voluntarily to removing mink over large areas. One such example is the Scottish Mink Initiative, where a range of local interested parties, including gamekeepers, fisheries staff, wildlife conservation professionals, land managers and local residents, collaborated to successfully control mink in an area of $>29,000 \mathrm{~km}^{2}$ in and around Cairngorms National Park (Bryce et al., 2011; Robertson et al., 2016). Alternatively, monetary rewards (i.e. extrinsic motivation) could be offered to incentivize hunters to trap mink. Uncritical use of economic rewards such as bounties could potentially reduce the intrinsic motivations for mink control over the long term; however, in circumstances where there is little interest in conservation, monetary rewards may be the only option to recruit hunters and trappers to the campaign (Gosling \& Baker, 1989; Rode et al., 2015). Social benefits are also important for volunteer retention in conservation campaigns (e.g. Ryan et al., 2001; Asah \& Blahna, 2012). Hunters could be motivated by hunting together with friends and family (Kaltenborn et al., 2012), and providing social networking arenas could be crucial for the success of long-term mink control campaigns. 
Alternatively, hunters could be more engaged in local conservation actions near their homes (Selinske et al., 2015), which would be advantageous as it would place less demand on individuals and avoid them overcommitting at the outset.

In Norway mink control programmes have had little success to date. Government-led bounty schemes were in operation during 1946-1975 (Bevanger \& Henriksen, 1995) but thereafter the responsibility was devolved to local municipalities to decide on bounty schemes. In 2013 only $27.78 \%$ of the 152 coastal municipalities from the five highest ranked counties for mink capture (SSB, 2013) provided bounties, of NOK 20-400 (EUR 2.36-47.33) per mink (J. Stien, unpubl. data). The Norwegian Environment Agency began a national-scale programme for mink control in 2011, including some additional economic rewards for mink catches (Direktoratet for Naturforvaltning, 2011; Stien et al., 2011). The national action plan highlighted a need for mink control, particularly in coastal areas, to establish mink-free areas to conserve vulnerable ground-nesting seabird species. The Norwegian Environment Agency attempted to increase awareness of and recruitment to the programme by collaborating with the Norwegian Association of Hunters and Anglers, which has 120,000 members (c. $2.5 \%$ of the Norwegian population; SSB, 2013), and met with participants of a successful citizen-initiated mink control programme at the World Heritage Site on Vega Island, in Nordland County (Supplementary Material 1). Finally, it was decided to train professional staff to undertake mink removal from a number of prioritized protected areas. During these government-led campaigns no scoping studies were initiated to investigate whether hunters and trappers shared a concern for the conservation of native species and would be willing to contribute to large-scale mink removal campaigns.

We investigated the possibility of including hunters and trappers in large-scale collaborative campaigns in Norway. We assumed that hunters and trappers who were concerned about the conservation of native species would be more willing to participate voluntarily in mink removal campaigns. More specifically, we expected that hunters with strong consumptive and conservation motives would maximize their catches compared to those with more appreciative motives (e.g. relaxation, excitement, experiencing nature, sensu Kaltenborn et al., 2012), and that those who hunted primarily for consumptive reasons would be more likely to be concerned about the protection of fish and game species rather than species of conservation concern. We also expected that hunters who received bounty would catch the most mink, indicating the potential of financial incentives to increase captures. We discuss our results together with the type of leadership preferred by hunters and their suggestions to improve mink hunting, and compare our results with the experiences of large-scale removal programmes elsewhere.

\section{Methods}

\section{Survey questionnaire}

We designed an internet survey in Questback (Questback, Oslo, Norway), targeted at mink hunters (Table 1). The questionnaire was tested on a subset of eight respondents and employees of the Norwegian Association of Hunters and Anglers and amended based on their feedback before being made available to other respondents. The questionnaire consisted of 47 questions, including questions about the number of mink caught and general hunting effort during the 2012 hunting season (1 April 2012-31 March 2013), respondents' motivation for mink hunting (based on Kaltenborn et al., 2012), and payment of bounty (Fulton et al., 1996). To explore possible forms of leadership of mink control programmes we asked hunters who they thought should be responsible for mink control. We also asked them to state the relative importance of personal, social and conservation benefits in motivating them to hunt (Asah \& Blahna, 2013), and to check one or more statements describing why they hunt. We supplemented these general questions with more specific questions to elicit attitudes and intent to participate in mink control for conservation purposes. These included questions about perceived threats of mink to fish, game and threatened species, and the importance of mink removal from protected areas, including nature reserves, National Parks, World Heritage Sites and other specially protected areas. The variable Red List species of bird (based on the 2010 Norwegian Red List; Kålås et al., 2010) was aggregated to include the black guillemot Cepphus grylle, puffin Fratercula arctica, black-throated diver Gavia arctica and common scoter Melanitta nigra, which were perceived to be threatened by mink. The variable groundnesting species not on the Red List refers to the common eider Somateria mollissima and other ground-nesting birds. We included threat to salmon and other salmonids as a separate variable. There were two questions on mink-hunting behaviour (Table 1), to investigate how motivations and conservation attitudes affected the number of mink caught and the effort invested in mink hunting. We analysed the number of hunting days and intentions to remove mink during the next 3 years, but we only retained mink catches in the 2012 season as our analyses showed a significant correlation among these three variables.

With a view to setting up a conservation programme targeted towards removing mink, we asked respondents who they thought should be in charge of such a programme. As this was the first study targeted towards mink hunters in Norway, we wanted to ensure that we identified a broad range of challenges and alternatives for initiating control programmes. We therefore included an open question inviting respondents to contribute suggestions that could improve mink hunting. The questionnaire and ethics were 
TABLE 1 Variables used in analysis of the perceptions of Norwegian mink hunters, based on survey questions about the 2012 hunting season.

\begin{tabular}{|c|c|}
\hline Variable & Question \\
\hline Motivation & $\begin{array}{l}\text { Tick one or more statements that are appropriate for you. } \\
\text { I like to hunt or fish because: } \\
\text { 1. Family or friends hunt (social). } \\
\text { 2. It gives me a sense of belonging to a group I wanted to be part of (social). } \\
\text { 3. It gives me exciting experiences (appreciative). } \\
\text { 4. I think it is important to harvest from nature (consumptive). } \\
\text { 5. It increases my knowledge about quarry species (appreciative). } \\
\text { 6. I like to eat fresh fish and/or game that come directly from nature (consumptive). } \\
\text { 7. It is an outdoor hobby that is close to where I live (local). } \\
\text { 8. It gives me the opportunity to experience impressive nature (appreciative). } \\
\text { 9. It is a good form of relaxation (therapeutic). } \\
\text { 10. It gives me physical activity (therapeutic). } \\
\text { 11. I can contribute to conservation and/or management of nature (conservation). }\end{array}$ \\
\hline Leadership & $\begin{array}{l}\text { Who do you think should lead programmes aimed at controlling mink? } \\
\text { 1. The Norwegian Environment Agency (national government) } \\
\text { 2. County government offices (regional government) } \\
\text { 3. Municipalities } \\
\text { 4. Landowners } \\
\text { 5. The Norwegian Hunting and Fishing Association/other NGOs } \\
\text { 6. Individuals must take responsibility for controlling mink }\end{array}$ \\
\hline Bounty & $\begin{array}{l}\text { Do you receive funding from the municipality (and if so, how much)? } \\
\text { 1. No } \\
\text { 2. NOK } 1-99 \\
\text { 3. NOK } 100-199 \\
\text { 4. NOK } 200-399 \\
\text { 5. NOK } 400-499 \\
\text { 6. NOK }>500\end{array}$ \\
\hline Conservation attitudes & $\begin{array}{l}\text { Presence/absence of the following conservation attitudes (combined from several questions, as described in the text). } \\
\text { 1. Mink is a threat to Norwegian biodiversity. } \\
\text { 2. It is important to remove mink from protected areas. } \\
\text { 3. It is important to remove mink to protect threatened species of birds. } \\
\text { 4. It is important to remove mink to protect ground-nesting species. } \\
\text { 5. It is important to remove mink to protect salmonid fish. }\end{array}$ \\
\hline Mink hunting & $\begin{array}{l}\text { 1. How many mink did you trap or shoot during the } 2012 \text { season? } \\
\text { 2. Do you intend to trap or shoot mink during the next } 3 \text { years? } \\
\text { 3. How many days did you hunt during the } 2012 \text { season? }\end{array}$ \\
\hline Recommendations & Can you suggest some ways to motivate or make it easier for hunters to remove mink? \\
\hline
\end{tabular}

reviewed and approved by the Norwegian Social Science Data Services (project number 34676).

\section{Survey administration}

Our study was intended to gather knowledge to inform the design and elucidation of alternative strategies for a targeted volunteer and incentive programme. As there is no arena for recruiting mink hunters directly we decided to recruit broadly through the Norwegian Association of Hunters and Anglers. With their cooperation we advertised the questionnaire in a news item in September 2013, both on their website's homepage and in their monthly magazine, with a link to the electronic questionnaire. This was followed 6 weeks later by direct e-mail contact with all of the Association's county level $(n=19)$ and municipality $(n=509)$ groups, as well as the 152 local government authorities in the five counties with the highest mink returns in the 2012 hunting season. The e-mail explained the goals of the project and asked for contact information for potential respondents. The e-mail to groups belonging to the Norwegian Association of Hunters and Anglers also asked that the survey be promoted at county and municipality level. We followed up contacts by telephone and raised awareness of the study by means of local radio. 


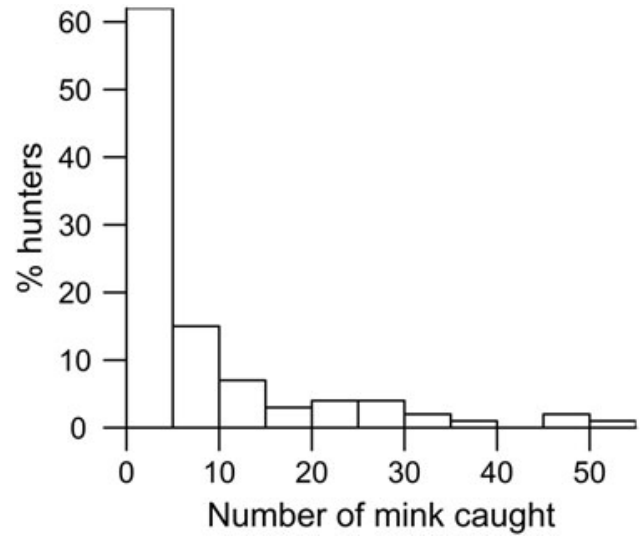

FIG. 1 The percentage of hunters who caught various numbers of American mink Neovison vison during the 2012 hunting season.

\section{Data analysis}

We received 104 completed surveys. We used multiple correspondence analysis (Tenenhaus \& Young, 1985) to explore the categorical data on motivation and leadership variables, and the results (i.e. coordinates) from this analysis were used to create classes of motivation and leadership data by agglomerate hierarchical clustering. Clusters were determined using a Euclidean distance metric for coordinate distances, and Ward's method was used to define optimum clusters (Ward, 1963; Husson et al., 2010). Clustering was chosen because of the small sample size, and the analyses were carried out in the package FactoMineR (Husson et al., 2015) in $R v .3 .12$ (R Development Core Team, 2015).

We used generalized linear regression, assuming a Poisson error distribution, to model the number of mink caught as a function of the variables bounty and motivation. We used cumulative logistic models to predict the ordinal dependent variables conservation attitudes and leadership from motivation using the $\mathrm{clm}$ function with a probit link in the $R$ package ordinal (Christensen, 2015). The best model was chosen based on the Akaike Information Criterion corrected for small sample sizes (AICc; Burnham \& Anderson, 2002) using the $R$ package AICcmodavg (Mazerolle, 2016).

\section{Results}

One hundred and four respondents answered the questionnaire, of whom 96 were members of the Norwegian Association of Hunters and Anglers. Although the sample size is statistically small, it represents hunters who are reportedly responsible for a high number of mink caught in Norway during the 2012 season (a total of 1,053 mink, mean 12.84, range 1-80 per hunter). Their reported catch represents a significant percentage $(19.87 \%)$ of the total national catch for the 2012 season (SSB, 2013). More than $60 \%$ reportedly caught fewer than five mink during the
2012 season, which suggests that a large proportion of the mink are being caught by only a few hunters (Fig. 1). The mean age of respondents was 41.29 years (range 16-76 years); most were male ( $96 \%)$, lived in coastal municipalities $(86 \%)$ and hunted in their residential or neighbouring municipality $(91 \%, \mathrm{n}=90)$.

The effect of bounty, motivation and hunting effort on the number of mink caught

Almost all mink hunters subscribed to conservation, consumptive and appreciative reasons for hunting (Table 2). Differences among hunters were captured only by two variables, 'whether they like to hunt with family and friends' (social) and 'whether they like to hunt close to where they live' (local), which also explains the differences among the three classes identified by clustering. For the 2012 hunting season hunters who reported enjoying hunting alone and not necessarily locally were estimated to catch on average 1.87 more mink than those who reported hunting locally (estimated effect of non-social, non-local motivation: $8.06 \pm$ SE 1.09 mink, $\mathrm{P}<0.001$ ). In the same season hunters who like to hunt with family and friends were estimated to catch 1.39 more mink than hunters who like to hunt locally (estimated effect of hunting for social reasons: $7.58 \pm$ SE 0.08 mink, $\mathrm{P}<0.001$ ). Estimates from the model predicting the number of mink caught (Fig. 2) indicate that receiving bounty increased the mean reported number of mink caught by 4.70 (estimated effect of reference value (no bounty) on reported mink catch frequency: 6.19 \pm SE 1.07 mink; estimated effect of bounty on reported mink catch frequency: $10.89 \pm \mathrm{SE} 1.07$ mink, $\mathrm{P}<0.001)$. Three outliers that had a large effect on the coefficient estimates were removed. Inspection of the model residuals indicated that standard deviations were larger than expected when theoretical quantiles were $>_{1}$ or $<1$.

Most hunters reported being interested in removing mink to aid conservation management (Table 3), agreeing strongly that mink are a threat to Norwegian biodiversity and that they should be removed from protected areas. Hunters believed it was more important to remove mink to conserve ground-nesting species such as eider and grouse than focusing on specific ground-nesting species from the Red List (Table 3). Opinion was divided regarding the protection of salmonid fishes. Motivations were not significant in predicting conservation attitudes.

\section{Leadership and recommendations for conservation targeted towards mink control campaigns}

Leadership classes were best defined by three clusters (Table 4). Cluster 1 consisted of $47 \%$ of the respondents, who reported a preference for government-led campaigns, 
TABLE 2 Descriptive values of categories of hunters' reported motivations to hunt mink, as defined by hierarchical agglomerative clustering (see text for details), with the number of hunters $(n=101)$ in each cluster. The $\mathrm{v}$ test is a transformation of the $\mathrm{P}$ value, with values $>$ or $<2$ denoting statistical significance of the linkage between categories at $\mathrm{P}<0.05$ (Husson et al., 2015). As the software provides v-test values only for $\mathrm{P}<0.05$, values for $\mathrm{P} \geq 0.05$ are denoted by NS (non-significant).

\begin{tabular}{|c|c|c|c|c|c|c|c|c|}
\hline Motivation variables & Local & $\mathrm{v}$ test $^{*}$ & $\begin{array}{l}\text { Non-social, } \\
\text { non-local }\end{array}$ & v test ${ }^{*}$ & Social & $\begin{array}{l}\mathrm{v} \\
\text { test }^{*}\end{array}$ & $\begin{array}{l}\text { Global } \\
\text { mean }\end{array}$ & $\begin{array}{l}\text { No. of respondents } \\
\text { agreeing with statement }\end{array}$ \\
\hline It gives me exciting experiences. & & NS & & NS & & NS & & 93 \\
\hline $\begin{array}{l}\text { I think it is important to harvest } \\
\text { from nature. }\end{array}$ & & NS & & NS & & NS & & 92 \\
\hline $\begin{array}{l}\text { It gives me the opportunity to } \\
\text { experience impressive nature. }\end{array}$ & & NS & & NS & & NS & & 91 \\
\hline $\begin{array}{l}\text { I can contribute to conservation } \\
\text { and/or management of nature. }\end{array}$ & & NS & & NS & & NS & & 88 \\
\hline It is a good form of relaxation. & & NS & & NS & & NS & & 87 \\
\hline It gives me physical activity. & & NS & & NS & & NS & & 84 \\
\hline $\begin{array}{l}\text { I like to eat fresh fish and/ or game } \\
\text { that come directly from nature. }\end{array}$ & & NS & & NS & & NS & & 84 \\
\hline $\begin{array}{l}\text { It gives me a sense of belonging to a } \\
\text { group I want to be part of. }\end{array}$ & & NS & & NS & & NS & & 79 \\
\hline $\begin{array}{l}\text { It is an outdoor hobby that is close } \\
\text { to where I live. }\end{array}$ & 33 & 3.59 & 0 & -5.19 & & NS & 32 & 64 \\
\hline $\begin{array}{l}\text { It increases my knowledge about } \\
\text { quarry species. }\end{array}$ & & NS & & NS & & NS & & 63 \\
\hline Family or friends hunt. & 0 & -5.23 & 0 & -4.13 & 44 & 7.76 & 22 & 44 \\
\hline
\end{tabular}

* Values of $>2$ are significant at the $\mathrm{P}<0.05$ level, indicating that the frequency of respondents agreeing (positive) or disagreeing (negative) with the statement is larger or smaller than the mean number of respondents agreeing with the statement (global mean).

respondents in cluster 2 reported a preference for NGO leadership and were negative towards municipal involvement $(33 \%)$, and respondents in cluster 3 reported a preference for self-initiated and landowner actions to hunt and were against any hierarchical-led actions (20\%).

The majority of hunters $(86 \%)$ recommended one or more ways that mink hunting could be made more appealing, with bounty (52\%) and raising awareness and increasing recruitment of mink hunters (36\%) being common to all leadership classes (Table 5). The recommendation of more logistical and financial support for undertaking mink hunting $(29 \%)$ was supported equally by those in favour of governmental and NGO-led mink control programmes, but not by hunters favouring landowner or self-initiated mink removal (Table 5). The recommendation of centralizing the organization of landowner permissions was supported only by those emphasizing government-led programmes (Table 5). Most recommendations were not directed explicitly towards a specific leadership class. A third of hunters recommended that bounty should be increased to attract mink hunters.

\section{Discussion}

The overall insight gained from this study is that recruitment to, and interest in, mink control programmes in Norway is low. Previous attempts to set up such

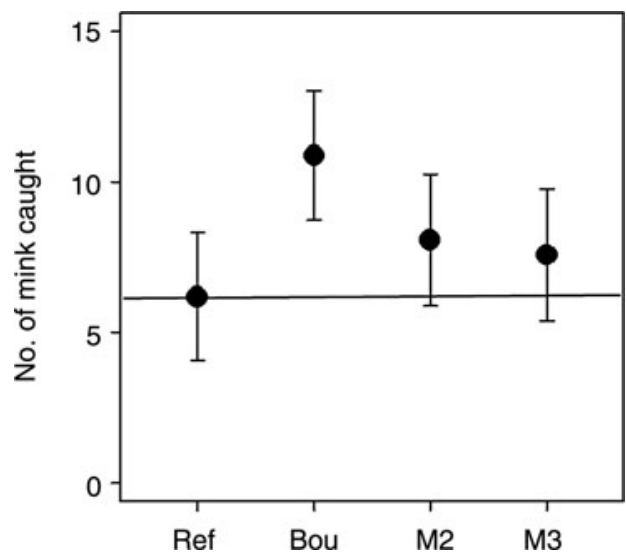

FIG. 2 The exponential of the Poisson error regression estimates of the effects of motivation (M) and bounty on the number of mink caught by 101 mink hunters during the 2012 hunting season. The reference level is the number of mink caught by hunters motivated to hunt near home and not receiving a bounty. M2, non-social and non-local hunters; $\mathrm{M}_{3}$, social hunters.

programmes and our extensive efforts to recruit participants in our study suggest a low potential for large-scale collaborative efforts at present. The few mink hunters who participated in the study accounted for $19.9 \%$ of the reported mink catches in the 2012 hunting season, which implies that a few hunters are responsible for a significant portion of the mink harvest in Norway. Mink hunters in receipt of 
TABLE 3 Percentage of conservation attitudes expressed by hunters in the self-reported motivation classes: local; non-social, non-local; social. We found no significant differences among classes.

\begin{tabular}{|c|c|c|c|c|c|c|}
\hline \multirow[b]{2}{*}{ Conservation values } & \multicolumn{2}{|c|}{ Local } & \multicolumn{2}{|c|}{$\begin{array}{l}\text { Non-social, } \\
\text { non-local }\end{array}$} & \multicolumn{2}{|c|}{ Social } \\
\hline & Yes & No & Yes & No & Yes & No \\
\hline Mink is a threat to Norwegian biodiversity. & 28 & 4 & 35 & 1 & 39 & 4 \\
\hline It is important to remove mink from protected areas. & 31 & 1 & 24 & 2 & 35 & 8 \\
\hline It is important to remove mink to protect threatened species of birds. & 8 & 24 & 5 & 21 & 19 & 24 \\
\hline It is important to remove mink to protect ground-nesting species. & 26 & 6 & 34 & 2 & 28 & 5 \\
\hline It is important to remove mink to protect salmonid fish. & 21 & 11 & 7 & 19 & 21 & 22 \\
\hline
\end{tabular}

TABLE 4 Descriptive values of categories of hunter-reported preference for leadership, as defined by hierarchical agglomerative clustering (see text for details), with the number of hunters $(n=101)$ in each cluster. The $v$ test is a transformation of the $P$ value, with values $>$ or $<2$ denoting statistical significance of the linkage between categories at $\mathrm{P}<0.05$ (Husson et al., 2015). As the software provides v-test values only for $\mathrm{P}<0.05$, values for $\mathrm{P} \geq 0.05$ are denoted by NS (non-significant).

\begin{tabular}{|c|c|c|c|c|c|c|c|c|}
\hline Leadership variables & Government & $\mathrm{v}$ test $^{*}$ & NGO & v test ${ }^{*}$ & Individual & $v$ test $^{*}$ & Global mean & $\begin{array}{l}\text { No. of respondents } \\
\text { in agreement }\end{array}$ \\
\hline $\begin{array}{l}\text { The Norwegian Environment } \\
\text { Agency }\end{array}$ & 33 & 2.75 & & NS & 2 & -2.81 & 28.5 & 57 \\
\hline The county government offices & 23 & 2.11 & & NS & 0 & -3.17 & 20.0 & 40 \\
\hline The municipalities & 37 & 3.24 & 16 & -3.16 & & NS & 31.0 & 62 \\
\hline Landowners & & NS & & NS & 11 & 2.25 & 18.5 & 37 \\
\hline $\begin{array}{l}\text { The Norwegian Hunting and Fishing } \\
\text { Association/other NGOs }\end{array}$ & 0 & -5.69 & 33 & 7.36 & 0 & -2.75 & 26.5 & 33 \\
\hline $\begin{array}{l}\text { Individuals must take responsibility } \\
\text { for controlling mink }\end{array}$ & 8 & -3.64 & & NS & 20 & 4.97 & 23.5 & 47 \\
\hline
\end{tabular}

${ }^{*}$ Values of $>2$ are significant at the $\mathrm{P}<0.05$ level, indicating that the frequency of respondents agreeing (positive) or disagreeing (negative) with the statement is larger or smaller than the mean number of respondents agreeing with the statement (global mean).

bounty caught substantially more mink than those who were not, and increasing bounty payments as well as awareness were among the main recommendations provided by respondents. Offering bounties has not always succeeded in reducing populations of invasive species over time (Thompson, 1962; Gosling \& Baker, 1989; Bevanger \& Henriksen, 1995); however, given the low interest in mink hunting at present, it could help to recruit more hunters to remove mink from strategically planned buffer areas. Financial incentives should be planned carefully to avoid crowding-out effects (i.e. participation for economic rewards rather than to conserve fish, game or threatened species) but can be beneficial, having reportedly increased the feeling of intrinsic motivation in cases where it had been lacking previously (i.e. crowding-in effects; Rode et al., 2015). For example, goal-oriented incentives that reward staff for completing eradication has proved successful in coypu Myocastor coypus removal programmes in the UK (Gosling \& Baker, 1989), and seasonal bonus payments (e.g. for independently assessed mink-free areas at the start of the breeding season) could be included as part of the collaborative campaign in prioritized conservation areas. To avoid recolonization and to recruit a larger pool of mink hunters to the campaign, bounty programmes should continue in the buffer areas surrounding the core conservation areas.

The general willingness to remove mink to protect ground-nesting birds is not surprising given the strong support for recreational grouse hunting in Norway (Kaltenborn et al., 2012). However, mink hunters appear to be less concerned about threatened species prioritized by the Norwegian Environment Agency. Awareness and recruitment campaigns aimed at increasing hunters' interest in removing mink may be more successful if there is a perceived threat to popular harvestable species, such as grouse, eider or salmonid species. The case study from Vega World Heritage Site indicates that hunters can be motivated to participate in mink removal programmes to protect seabird colonies, possibly in part because of a feeling of historical cultural identity. In Vega the interest in mink removal reflects a strong cultural history, as coastal communities were sustained economically by the eider down industry until the 1940 (e.g. Soot-Ryen, 1941).

Several studies have indicated that social benefits are important in maintaining long-term participation in 
TABLE 5 Recommendations to make mink hunting more appealing, with the categories of leadership preferred by the hunters (government, NGO, individual). Numbers of hunters in each category are shown, with examples of statements from 86 mink hunters who were active during the 2012 hunting season.

\begin{tabular}{|c|c|c|c|}
\hline \multirow[b]{2}{*}{ Recommendation } & \multicolumn{3}{|c|}{ Leadership category } \\
\hline & Government & NGO & Individual \\
\hline $\begin{array}{l}\text { Bounty } \\
\text { Bounty for mink would have helped a lot, I think } \\
\text { Higher bounty }\end{array}$ & 19 & 16 & 10 \\
\hline $\begin{array}{l}\text { Awareness \& recruitment } \\
\text { Local groups buy in traps for young hunters \& others interested } \\
\text { Instruction \& [the possibility of] increasing skills } \\
\text { Raise awareness of what a scourge mink is } \\
\text { More focus on publicizing the consequences of mink predation } \\
\text { Increase understanding of the destruction of natural wildlife by mink } \\
\text { Better information regarding where it is possible to hunt } \\
\text { Better information for landowners so that it is easier to get permission }\end{array}$ & 13 & 12 & 6 \\
\hline $\begin{array}{l}\text { Equipment \& costs } \\
\text { Easier access to traps } \\
\text { Grant to cover traps \& ammunition } \\
\text { It would have been nice to be given some traps } \\
\text { Economical support \& free traps } \\
\text { It would have been nice with economical support. . . because ammunition \& fuel for boats has become } \\
\text { so expensive }\end{array}$ & 12 & 12 & 1 \\
\hline $\begin{array}{l}\text { Organization of landowner permission } \\
\text { Easier to get permission from landowners } \\
\text { Organization of landowners [access] } \\
\text { Landowners that allow access to hunting } \\
\text { That more landowners let us set up traps or hunt }\end{array}$ & 9 & 1 & 1 \\
\hline $\begin{array}{l}\text { Changes in law } \\
\text { It should be possible to shoot from a motor boat } \\
\text { There should be free hunting of mink on uninhabited islands along coast with holms \& islands } \\
\text { Remove landowner permission } \\
\text { Lawful to use } 22 \text { caliber ammunition as in Sweden }\end{array}$ & 4 & 5 & 2 \\
\hline
\end{tabular}

collaborative efforts (e.g. Ryan et al., 2001; Asah \& Blahna, 2012), in agreement with previous findings for small game hunters (Andersen et al., 2008). These studies point to a positive relationship between volunteer retention and a sense of belonging fostered by hunting together with friends and family or by membership of local cultures (Selinske et al., 2015). In our study most mink were removed by hunters who reportedly preferred to hunt alone and not necessarily near their home. These patterns may reflect a lack of game or conservation species of interest in their local area, that mink has already been removed, or that the hunters' goal was to maximize catch in high-density localities. In terms of mink catches, hunters who preferred to hunt with family and friends caught more mink than those who preferred to hunt locally. Creating social arenas for mink hunters from various local communities to meet and share their experiences could potentially engage their interest in catching more mink.

We believe that any mink removal campaigns would have to be adapted to the socio-political context of the target area. Most of the examples of volunteer-based programmes for the removal of invasive alien species are from Britain, the USA and Australia (Silvertown et al., 2013), where conservation-oriented volunteer work in general is more widespread. In Norway only $3.8 \%$ of the population volunteered in conservation-related work in 2002, compared to $5.9 \%$ in Sweden and $8.9 \%$ in the UK (European Social Survey, 2002). In Norway, environmental conservation is organized differently, derived from the corporatist style of governance common to all Scandinavian countries (Dryzek et al., 2002). All organizations, including conservation organizations, are perceived as the arms of the state, and receive financial and logistical support from the government. It is therefore not surprising that hunters prefer topdown initiatives led by the government or the Norwegian Association of Hunters and Anglers to programmes initiated by citizens or landowners. Organizing mink control programmes as collaborative efforts between the government, municipalities and the Norwegian Association of Hunters and Anglers is sensible given the number of local 
organizations represented by the Norwegian Association of Hunters and Anglers, and the financial and logistical support the government could provide. The hunters who responded to our survey requested that the government play a more active role in providing infrastructure, bounty, and trapping equipment, organizing landowner permissions to hunt, and setting up recruitment and education programmes to increase participation in mink hunting.

We conclude that there is currently little interest in mink hunting in Norway. The Environment Agency has opted to train its own staff to remove mink from a small number of coastal islands with high conservation priority for groundnesting seabird species, using guns and tracking dogs. However, these reserves represent only a small fraction of Norway's coastline cohabited by mink and vulnerable native prey species. Collaborative efforts involving hunters to control the red fox Vulpes vulpes population in Norway indicate that effective control is feasible by a combination of contractual operators (i.e. The Norwegian Environment Agency State Supervisor Inspectorate), hunting organizations and bounty payment (which in this case was notably higher than in any mink control programme). We recommend trialling a similar collaborative approach, with hunter activity concentrated in buffer zones of priority core conservation areas, with potential for expansion to additional areas. This could be implemented, for example, by offering seasonal target-based bonus payments for early delivery before the breeding season of ground-nesting birds. We suggest that this approach could lead to effective larger-scale control of mink in coastal Norway, and serve as a case study of mink control for other countries characterized by generally low volunteer participation in conservation projects.

\section{Acknowledgements}

This work has been funded by the Norwegian Environment Agency, the County Governor of Troms and the University of Tromsø, Norway's Arctic University. We are grateful for the comments of two anonymous reviewers.

\section{Author contributions}

JS and VHH designed the study and questionnaire, analysed the data and wrote the article. JS collected and collated the data.

\section{References}

Ahola, M., Nordström, M., Banks, P.B., Laanetu, N. \& KorpimäKi, E. (2006) Alien mink predation induces prolonged declines in archipelago amphibians. Proceedings of the Royal Society B: Biological Sciences, 273, 1261-1265.
Andersen, O., Kaltenborn, B.P., Pedersen, H.C., Storaas, T., FAYE-SCHJøLL, E. \& SolvANG, H. (2008) Spørreundersøkelse blant rypejegere etter jaktsesongen 2006/o7. Datagrunnlag og noen sentrale funn fra Rypeforvaltningsprosjektet 2006-2011. NINA Rapport, 379, 44.

Asah, S.T. \& Blahna, D.J. (2012) Motivational functionalism and urban conservation stewardship: implications for volunteer involvement. Conservation Letters, 5, 470-477.

Asah, S.T. \& Blahna, D.J. (2013) Practical implications of understanding the influence of motivations on commitment to voluntary urban conservation stewardship. Conservation Biology, 27, 866-875.

Bevanger, K. \& Henriksen, G. (1995) The distributional history and present status of the American mink (Mustela vison Schreber, 1777) in Norway. Annales Zoologici Fennici, 32, 11-14.

Bonesi, L. \& Palazon, S. (2007) The American mink in Europe: status, impacts, and control. Biological Conservation, 134, 470-483.

Bryce, R., Oliver, M.K., Davies, L., Gray, H., Urquhart, J. \& Lambin, X. (2011) Turning back the tide of American mink invasion at an unprecedented scale through community participation and adaptive management. Biological Conservation, 144, 575-583.

Burnham, K.P. \& Anderson, D.R. (2002) Model Selection and Multimodel Inference: A Practical Information-Theoretic Approach. Springer, New York, USA.

Christensen, R.H.B. (2015) Package 'ordinal': Regression models for ordinal data. R package version 2015. 6-28. Https://cran.r-project. org/web/packages/ordinal/ordinal.pdf [accessed 5 October 2016].

Dryzek, J.S., Hunold, C., Schlosberg, D., Downes, D. \& Hernes, H.K. (2002) Environmental transformation of the state: the USA, Norway, Germany and the UK. Political Studies, 50, 659682.

Direktoratet for Naturforvaltning (2011) Handlingsplan mot mink. DN - rapport 5-2011.

European Social Survey (2002) Round 1. Http://www. europeansocialsurvey.org/data/country_index.html [accessed 24 October 2016].

Fulton, D.C., Manfredo, M.J. \& Lipscomb, J. (1996) Wildlife value orientations: a conceptual and measurement approach. Human Dimensions of Wildlife, 1, 24-47.

Gosling, L.M. \& BAKER, S.J. (1989) The eradication of muskrats and coypus from Britain. Biological Journal of the Linnean Society, 38 , 39-51.

Husson, F., Josse, J. \& PAGÈs, J. (2010) Principal component methods - hierarchical clustering - partitional clustering: why would we need to choose for visualizing data? Technical report. Agrocampus Ouest, Rennes, France.

Husson, F., Josse, J., Le, S. \& Mazet, J. (2015) Multivariate exploratory data analysis and data mining with R. Https://rdrr.io/ cran/FactoMineR/man/FactoMineR-package.html [accessed 5 October 2016].

KÅlÅs, J.A., Viken, Å., Henriksen, S. \& Skjelseth, S. (2010) The 2010 Norwegian Red List for Species. Norwegian Biodiversity Information Centre, Trondheim, Norway.

Kaltenborn, B.P., Andersen, O., Vitters $\emptyset$, J. \& Bjerke, T.K. (2012) Attitudes of Norwegian ptarmigan hunters towards hunting goals and harvest regulations: the effects of environmental orientation. Biodiversity and Conservation, 21, 3369-3384.

Kettunen, M., Genovesi, P., Gollasch, S., Pagad, S., Starfinger, U., ten Brink, P. \& Shine, C. (2008) Technical Support to EU Strategy on Invasive Alien Species (IAS): Assessment of the Impacts of IAS in Europe and the EU. Final module report for the European Commission. Institute for European Environmental Policy, Brussels, Belgium. 
Mazerolle, M.J. (2016) Model selection and multimodel inference based on (Q) AIC(c). Version 2.0-4. Https://cran.r-project.org/web/ packages/AICcmodavg/AICcmodavg.pdf [accessed ${ }_{5}$ October 2016].

Nordström, M., Högmander, J., Laine, J., Nummelin, J., LAanetu, N. \& KorPIMÄKI, E. (2003) Effects of feral mink removal on seabirds, waders and passerines on small islands in the Baltic Sea. Biological Conservation, 109, 359-368.

Poorter, M.D., Pagad, S. \& Ullah, M.I. (2007) Invasive Alien Species and Protected Areas. A Scoping Report. Http://www.issg.org/ pdf/publications/gisp/resources/ias_protectedareas_scoping_i.pdf [accessed 5 October 2016].

R Development Core Team (2015) R: A Language and Environment for Statistical Computing. R Foundation for Statistical Computing, Vienna, Austria.

Reynolds, J.C. (2009) American mink: the art of the possible and national aspirations of biodiversity. International Urban Ecology Review, 4, 74-82.

Robertson, P.A., Adriaens, T., Lambin, X., Mill, A., Roy, S., Shuttleworth, C.M. \& Sutton-Croft, M. (2016) The large-scale removal of mammalian invasive alien species in Northern Europe. Pest Management Science, https://doi.org/10.1002/ ps.4224.

Rode, J., Gómez-Baggethun, E. \& Krause, T. (2015) Motivation crowding by economic incentives in conservation policy: a review of the empirical evidence. Ecological Economics, 117, 270-282.

Ryan, R.L., Kaplan, R. \& Grese, R.E. (2001) Predicting volunteer commitment in environmental stewardship programmes. Journal of Environmental Planning and Management, 44, 629-648.

Selinske, M.J., Coetzee, J., Purnell, K. \& Knight, A.T. (2015) Understanding the motivations, satisfaction, and retention of landowners in private land conservation programs. Conservation Letters, 8, 282-289.

Sheall, J. (2004) The mink menace: the politics of vertebrate pest control. Rural History, 15, 207-222.
Silvertown, J., Buesching, C.D., Jacobson, S.K. \& Rebelo, T. (2013) Citizen science and nature conservation. In Key Topics in Conservation Biology 2 (eds D.W. Macdonald \& K.J. Willis), pp. 124142. John Wiley \& Sons, Chichester, UK.

Soot-Ryen, T. (1941) Egg- og dunvær i Troms fylke Tromsø Museums årshefter, Naturhistorisk avd. Nr. 2062 (1939).

SSB (Statistisk Sentralbyr̊) (2013) Http://www.ssb.no/srjakt (archive).

Stien, J., Ims, R.A. \& Yoccoz, N.G. (2011) Invasive American Mink (Neovison vison): Status, Ecology and Control Strategies. Scientific Basis for Action Plan Against American Mink in Norway. The Norwegian Directorate for Nature Management, Trondheim, Norway.

Tenenhaus, M. \& Young, F.W. (1985) An analysis and synthesis of multiple correspondence analysis, optimal scaling, dual scaling, homogeneity analysis and other methods for quantifying categorical multivariate data. Psychometrika, 50, 91-119.

Thompson, H.V. (1962) Wild mink in Britain. New Scientist, 270, 130-132.

WARD, JR, J.H. (1963) Hierarchical grouping to optimize an objective function. Journal of the American Statistical Association, 58, 236-244.

\section{Biographical sketches}

JENNIFER STIEN is interested in conservation science, in particular the management of predator-prey interactions in birds of conservation concern, and human-predator conflicts resulting from the loss of Norwegian semi-domestic reindeer to protected large predators. Vera Helene Hausner has a broad interest in conservation science, focusing on interdisciplinary analyses of socio-ecological systems, ecosystem services, protected areas, community-based management and adaptive governance in Arctic and alpine areas. 